\title{
Coming in from the cold: how answering a postcard can launch a scientific career
}

\section{Gottfried Schatz}

"Here is that bio-something you wanted, Herr Doktor" mumbled the university librarian, pushing a pile of battered Physiologische Chemie textbooks in my general direction. His sarcasm was not lost on me, because he reserved 'Herr Doktor' for us students when we pestered him with extracurricular - hence frivolous - requests. Worse still, the biochemistry textbooks were pre-Second World War vintage. As we were then writing the year 1958, they were useless clunkers. After graduating from high school in the Austrian city of Graz, I had wanted to become a biochemist, but in those days the University of Graz had no biochemists on its faculty and offered no biochemistry courses of any kind. As my parents could not afford to send me abroad and as international fellowships were virtually nonexistent, I had decided to enrol as a chemistry student and to master biochemistry on my own. Thanks to my friendly librarian, I had just learned that textbooks from our university library were not an option. The bookstores in Graz carried only a single modern, but also prohibitively expensive, textbook by the Swiss biochemist Franz Leuthardt and were unwilling to find out what British or American publishers might have to offer. Such was the intellectual splendour of postwar Graz, which had once been home to such scientific giants as Otto Löwi, Karl Boltzmann, Ernst Mach and Erwin Schrödinger. After many false starts, I finally concocted the following six-step biochemistry course: first, I worked my way through the Biochemistry Section of Chemical Abstracts, a now defunct

Gottfried Schatz is Professor Emeritus at the Biozentrum of the University of Basel, Klingelbergstrasse 70, CH-5056, Switzerland and former president of the Swiss Science and Technology Council.

e-mail: gottfried.schatz@unibas.ch periodical that our library held. Second, I jotted down the names and addresses of the authors whose articles interested me. Third, I bought several dozen picture postcards of Graz and sent them to these authors with the lapidary handwritten request: "Please send me all your reprints". Fourth, fifth and sixth, I waited, waited and waited, because I could not afford the luxury of airmail and had sent all postcards by land mail. Looking back, I am amazed that anybody answered them at all. Yet quite a few did, sending me one or two of their most recent reprints. Not so David E. Green, a leading researcher on the biochemistry of mitochondria, who ran a huge and highly successful laboratory with several dozen collaborators at the Enzyme Institute of the University of Wisconsin at Madison. Green liked to do things the big way and sent me a massive package with more than 200 reprints on the function and structure of mammalian mitochondria. Some of these papers are now classics, and all of them bore the mark of Green's polished scientific prose. I devoured these articles, mostly on benches in our local park, and soon lost myself in an enchanted world of electron-conducting membranes and colourful cytochromes. What could be more exciting and important than the pathway that gave energy to life? My private biochemistry course had swung into high gear. Its balance of subjects may have been open to serious criticism, but it kindled my life-long fascination with cellular respiration and mitochondrial biogenesis.

I have never forgotten how anxiously I waited for replies to my postcards and how crucial David Green's generous response was for my scientific career. To this day I promptly answer every letter or e-mail I receive, particularly if it is from a young scientist whose name is unfamiliar to me. Scientists of today are so overburdened with paperwork and mesmerized by competition that they often neglect this simple courtesy. A thoughtful letter to a young scientist in a remote corner of the globe may do more for science than a plenary talk at an international meeting. Many of these meetings have degenerated into a mélange of commercial trade show and scientific media event where everybody flocks around the scientific stars. Many of these stars are so eager to rub shoulders with their illustrious peers that they have little inclination to waste their precious time talking to unknown young scientists. I have given my fair share of plenary talks and have usually enjoyed the limelight. But as I grew older, I became more conscious of the barrier between a plenary speaker and the younger congress participants. I often asked my hosts to excuse me from the after-speech presidential dinner table so that I could share my meal with groups of students I had never met before. Most of my hosts graciously accepted my excuse. The students usually rewarded me with refreshing insights and irreverent remarks about some of my colleagues, whereas I tried to reciprocate with advice on graduate schools, postdoctoral possibilities and faculty positions. And sometimes our talks ventured into deeper waters, such as the meaning of science and its role in the modern world.

Scientific discoveries are usually children of solitude, yet are rarely born in isolation. Science is a supremely communal effort, which demands that scientists share their discoveries and help one another. Science is a covenant between generations. By honouring this covenant so generously, David Green helped me get started in science and profoundly shaped my life. 